$\xi=-1$

\title{
Malaysian Public Private Partnership Projects: Project Success Definition
}

\author{
Usman Ahamd $^{1 *}$, Yusnidah Bt Ibrahim ${ }^{2}$, Arpah Bt Abu Bakar ${ }^{3}$ \\ ${ }^{I}$ PhD Scholar, School of economics, finance and banking, Universiti Utara Malaysia \\ ${ }^{2}$ Professor, School of economics, finance and banking, Universiti Utara Malaysia \\ ${ }^{3}$ Senior Lecturer, School of economics, finance and banking, Universiti Utara Malaysia \\ *Corresponding author E-mail: usmanahmadjee87@gmail.com
}

\begin{abstract}
In last few decades, many governments have been using Public Private Partnership (PPP) as a tool to provide infrastructure and public services. Most of PPP projects achieved the objectives whereas, a few are underachieved. Besides, prior literature does not provide robust definition of success for PPP projects. Although, project management literature defines the general definition of project success and explains success as variable. However, due to the distinct nature of PPP projects there is a need to redefine the PPP project success. Therefore, this study aims to provide robust definition of the success of PPP project based on distinct nature of PPP project. To achieve the objective, this study has adopted phenomenological research method and conducted semi-structured interviews. Thematic analysis has been carried out by using ATLAS-ti 8.0 to arrange interviews' data. Based on interviews, arrangements of two types of PPP projects, Build Lease Maintain and Transfer (BLMT) and Lease Maintain and Transfer (LMT) have been explained that leads to the development of the success criteria for PPP projects. The results reveal that one of the dimensions of success i.e. preparing for future is not valid to measure success for PPP projects.
\end{abstract}

Keywords: Public Private Partnership; Success; Success dimensions

\section{Introduction}

The provision of public services and infrastructure is the foremost responsibility of the government. However, scarcity of resources and incessant increase in demand tend government to involve private sector in provision of public services by creating partnership named as Public Private Partnership (PPP) (1). In addition, innovation, reduction of public money tied up in capital investment, reduction of the total project cost, in-time delivery of the project and local economic development are the factors that attract the Malaysian government to use PPP as tool for development of public infrastructure (2). Although, Malaysian government has been implementing PPP since the mid-1980s but allocation of funds in Ninth Malaysian Plan and enhanced plans of PPP projects in Tenth Malaysian Plan were the breakthrough in PPP development in Malaysia (1). Furthermore, Malaysian government developed a separate department under the direct supervision of Prime Minster named as Unit Kerjasama Awam Swasta (UKAS) in 2009 (3). However, difference in perception about critical issues and risks may create problems in implementing the PPP project (4).

Around the globe many PPP projects have failed due to many reasons (5). Similarly, in Malaysia Beh (6) reported the issues of patronage, cost benefit analysis and supervision; Markom and Ali (7) identified the problems of low cash flows and construction cost overrun in Light Rail Transit (LRT) and Tan (8) stated the reasons of underachievement of Water and Sanitation Services (WSS). Though, the area concerning the criterion to gauge the success for PPP is still underrepresented. The research in the field of PPP focuses on risk management, identification of critical success factors (CSFs), value for money calculation, governance issues, economic viability and procurement but success criteria is not available in a well-defined form (9). However, scarce resources require on part of the practitioners to gauge the level of success for high cost projects like those commonly found in PPP $(10,11)$. Moreover, Ika et. al (10) have also presented the success dimensions and construct for International Development projects (IDPs). However, the nature of PPP project is different than other projects due to the involvement of both public and private sectors $(1,4)$. Besides, according to Shenhar, Dvir, Levy and Maltz (12) success dimensions and measures depend on project type (i.e. low tech, medium tech or high tech) and time frame (i.e. long term or short term). Therefore, the same construct (measures) cannot be used for PPP. In addition, the difference in perception of both public and private sectors about critical issues is a reason to evaluate success for PPP projects.

Thus, this study first examines applicability of the already developed success dimensions and then defines the success for PPP projects. This result of the study may help the researcher to find the real critical success factors that affect the success significantly. These results may also help the practitioners to focus on those dimensions that make the project successful.

\section{Literature Review}

\subsection{Public Private Partnership}

In the last four decades, Public Private Partnership (PPP) has evolved as new tool for the provision of public services (13). 
However, academic researchers and practitioners still consider the concept of PPP as being 'very ambiguous' because of the wide range of arrangements in which level of involvement of the private sector varies (14). The involvement of both public and private parties that have difference in perception about critical issues make PPP a complex arrangement $(1,4)$. Different types of PPP arrangements (15) and level of participation of private sector are the two important factors to define PPP. The Canadian Council for PPP describes PPP as "[a] cooperative venture between the public and private sectors, built on the expertise of each partner, that best meets clearly defined public needs through the appropriate allocation of resources, risks and rewards" (16). The Prime Minister's PPP department Malaysia, defined PPP as "[a] form of cooperation between the public-private partnership in which a standalone business created, funded and managed by the private sector as a package which includes the construction, management, maintenance, repair and replacement of public sector assets include buildings, infrastructure, equipment and facility" (3). Although, consensus on one definition of PPP does not exist in literature but all researchers and practitioners agree on the fact that the PPP arrangements mean involvement of both public and private sectors, however, the level of involvement varies from region to region and project to project.

This study adopts the definition of PPP by Peters (17) and Li and Akintoye (18) in which a project is called PPP project if it has the certain characteristics. Firstly, a partnership comprises of two or more players; one of them is public and the other is private. Secondly, each partner acts as a principal and capable of negotiation. However, recently governments set up a separate agency (i.e. UKAS in Malaysia) that negotiates with private sector on behalf of government but does not enter in any contract. Thirdly, for oneoff transaction PPP is a continuous partnership which creates long-term relationships in certain parameters that are defined in PPP agreement. Fourthly, in PPP arrangements, each partner contributes something in terms of resources such as capital or land for the creation of a partnership. Lastly, the most important feature of PPP arrangements that differs from others is sharing of responsibilities, risks and outcomes.

\subsection{Project Success and Success Criteria}

Definition of project success lacks consensuses of authors and is a difficult concept to explain (11). From 1960 to 1980 achievement time/cost/quality goals was considered project success, however later the achievement of project objectives and satisfaction of stakeholders have been added to success criteria $(11,19)$. Project success means ability of project to complete/operate according to scheduled time, budgeted cost, predetermined performance levels and to satisfy client or end user (20). De Wit (21) explained project success as, achievement of time, cost, performance goals and achievement of predefined objectives. Different authors have explained dimensions of success in different words but almost same concept. Ika (2009) considered "Project Management (PM) success" (time, cost and quality/performance), "Project profile" and "Project impact" as dimensions of project success for international development projects. Wateridge (1998) described that successful IS/IT project must meet user requirements, timescale, project purposes, budget, quality and make user happy. The existing literature has identified the dimensions of success (Table 1).

Table 1: Success Dimensions in literature

\begin{tabular}{|c|c|c|}
\hline Dimensions & Definition & Authors \\
\hline Time & $\begin{array}{c}\text { Project must } \\
\text { achieve the goals of } \\
\text { timeframe }\end{array}$ & $\begin{array}{c}\text { Pinto and Slevin (20), De } \\
\text { Wit (21), Might and Fischer } \\
\text { (22), Baccarini (23), Shenhar } \\
\text { et al. (12) and Ika \& Thuillier } \\
(10)\end{array}$ \\
\hline Cost & $\begin{array}{c}\text { Actual cost should } \\
\text { not increase than } \\
\text { budgeted cost }\end{array}$ & $\begin{array}{c}\text { Pinto and Slevin (20), De } \\
\text { Wit (21), Might and Fischer } \\
\text { (22), Baccarini (23), Shenhar } \\
\text { et al. (12) and Ika \& Thuillier }\end{array}$ \\
\hline
\end{tabular}

\begin{tabular}{|c|c|c|}
\hline Quality & $\begin{array}{c}\text { Quality of opera- } \\
\text { tions/services provid- } \\
\text { ed or product should } \\
\text { be according to the } \\
\text { general thresholds }\end{array}$ & $\begin{array}{c}\text { Pinto and Slevin (20), De } \\
\text { Wit (21), Might and Fischer } \\
\text { (22), Baccarini (23), Shenhar } \\
\text { et al. (12) and Ika \& Thuillier } \\
(10)\end{array}$ \\
\hline $\begin{array}{c}\text { Achieve- } \\
\text { ment of project } \\
\text { Objectives }\end{array}$ & $\begin{array}{c}\text { Main objec- } \\
\text { tives/expected results } \\
\text { other than } \\
\text { time/cost/quality } \\
\text { should be achieved }\end{array}$ & $\begin{array}{c}\text { Might and Fischer (22), De } \\
\text { Wit (21) }\end{array}$ \\
\hline Stakeholder & $\begin{array}{c}\text { All stakeholders } \\
\text { should be satisfied } \\
\text { satisfaction project and } \\
\text { product/service }\end{array}$ & Pinto and Slevin (20) \\
\hline Preparation & $\begin{array}{c}\text { Project should be } \\
\text { ongoing according to } \\
\text { future needs of stake- } \\
\text { holders }\end{array}$ & $\begin{array}{c}\text { Shenhar et al. (12) and Ika } \\
\& \text { Thuillier (10) }\end{array}$ \\
\hline
\end{tabular}

Shenhar et al. (12) merged time and cost together and named as "Project Efficiency". According to Baccarini (23), quality means how much good the processes and functions are in terms of predefined Key Performance Indicators (KPIs), however, Might et al. (22) named it as "Technical Performance". Normally stockholder satisfaction includes client satisfaction, though, Pinto and Slevin (20) and Shenhar et al. (12) have discussed "client satisfaction" separately.

\section{Methodology}

The main objective of this research is to define project success as variable for PPP projects. Although dimensions of success exist in prior literature, but it is important to know the applicability of all dimensions in PPP projects. Creswell (24) suggests that phenomenological research method is helpful to inquire about any phenomenon or to inquire about experience of practitioners. Therefore, the current study adopts the phenomenological method to inquire the applicability of current project success criteria based on experience of PPP practitioners. In this method, based on guidelines of Groenewald (25), first the semi structured interviews were conducted. The interviewees were UKAS personals, BLMT experts in Ministry of Health, PPP experts in IIUM and PPP experts from Private companies that involve in PPP projects. Atlas-ti 8.0 is used to generate quotations from the interview data and to generate the themes/codes that helped to develop variable items.

Based on the findings of interviews, Phenomenon of Medical Equipment Enhancement Tenure (MEET) and International Islamic University Malaysia (IIUM) 5000 Bed project has been explained. Description of these projects and interview quotations leads the study to redevelopment the success definition in context of PPP projects.

\section{Interview Results and Discussion}

Based on the findings of interviews, the phenomenon of two types of PPP; Lease Maintain and Transfer (LMT) and Build Lease Maintain and Transfer (BLMT) projects has been explained then discussion of success criteria is explained.

\subsection{MEET Project (LMT)}

The Malaysian government has built small health clinics to provide the health services at the door step of public and to minimize the patient traffic at main hospital of city or state. Though, the maintenance of the infrastructure and medical equipment at each clinic is an expensive task. In order to operate these clinics efficiently the Ministry of Health $(\mathrm{MoH})$ has developed Medical Equipment Enhancement Tenure (MEET) maintenance program to supply and maintain the biomedical equipment. This program 
applies Lease Maintain and Transfer (LMT) model of PPP. However, MEET Program comprises of following three types of arrangements:

a) Existing Biomedical Equipment (EBE) - In this arrangement concession company maintains the already existing biomedical equipment the health clinics and $\mathrm{MoH}$ pays maintenance fees to concession company.

b) New Biomedical Equipment (NBE) - In this arrangement concession company purchases the new biomedical equipment valued at RM2000 and above. In addition, concession company maintain those equipment. $\mathrm{MoH}$ pays the price of those equipment in instalment and maintenance charges.

c) Purchased Biomedical Equipment (PBE) - In this arrangement concession company purchases biomedical equipment worth RM2000 or below. The concession company repurchases the equipment if it is out of order.

Through, the MEET program the Malaysian government saves the lumpsum fixed cost of purchase of biomedical, cost of installation of biomedical equipment and cost of staff for maintenance the biomedical equipment. In addition, this programme ensures the best quality and updated technology of biomedical equipment. However, MoH pays the purchase price for NBE and PBE program and maintenance cost in all three EBE, NBE and PBR in instalments. After the certain period mentioned in agreement (concession period), the $\mathrm{MoH}$ will get the ownership of all biomedical equipment and then $\mathrm{MoH}$ will maintain them or may create a new LMT agreement for maintenance.

For 2857 clinics in Penang, Perak, Kuala Lumpur, Selangor, Melaka, Johar, Lebuan and some parts of Sebah Quantum Medical Supply Sdn. Bhd. (QMS) has been awarded LMT agreement of worth RM1.3 billion for 13 years. The agreement was signed on 17 April 2014 and the effective date was 17 December 2014 Maintenance began at January 15, 2015 after maintenance bonds were submitted by the company. The period of 2014 was the planning phase for QMS in which it obtained the debt finance and completed the required documents. QMS is allowed 80:20 debt to equity ratio for financing. QMS must purchase all equipment in until December 2023 and maintain until 2027. However, before the purchase of any equipment, approval of supplier from $\mathrm{MoH}$ is mandatory. For QMS in-time purchase and quality of biomedical equipment is vital because delay in purchase or low quality of biomedical equipment may cause delay in rental payments from $\mathrm{MoH}$. In addition, cash flows depend upon the rental payments, maintenance frequency and maintenance cost. Failure in achieving budgeted cash flows may lead to financial crunch as QMS needs to pay the instalment of debt.

\subsection{IIUM-5000 Bed Hostel (BLMT)}

In BLMT model, a Special Purpose Vehicle (SPV) is granted a concession project to finance, build, and maintain public facility that is later rented to the government. The SPV builds a facility based on agreed design concept. After the construction of facility, the government uses the facility for public services and SPV receives rent/unitary charge. The SPV maintains the facility throughout the concession period. At the end of the concession period, the facility is transferred to the government in a specified working condition. The unitary charge includes maintenance charges and a fixed amount of rent of the facility. However, rent of facility depends on quality of service in accordance to Key Performance Indicators (KPIs) that are mentioned in concession agreement. In the agreement, there is a clause of review of rental payments (i.e. maintenance charges) after each specific interval period.

Sasaran etika sdn bhd (SESB) was awarded BLMT agreement in 2012 to build 5000-bed hostel for International Islamic University Malaysia (IIUM) situated in Pahang. SESB has built the hostel in 2014 and it has maintenance concession for $221 / 2$ years. Based on design concept, SESB completed the construction in scheduled time. However, for SESB achievement of budgeted cash flows are vital that depends on the rental payments. Government may deduct the certain amount if maintenance is not according to KPI.

\subsection{PPP Project Success}

Based on the interviews' quotations, with the help of Atlas ti 8.0 figure 1explains the PPP project success dimensions (Appendix A). In this figure "G" represents the number of quotations attached to the code and " $\mathrm{D}$ " shows the number of relations of each code with other codes. The detail discussion of each dimensions is as follows:

a) Time- For PPP project success, it is vital for a project to be completed in scheduled time. According to interviewees the PPP agreements are time-specific and based on certain demand forecast. The government initiate the project for the specific demand and SPV prepare a budget for specific period. In addition, pressure of public demands makes the time very crucial for both public and private partners. Therefore, to meet that demand at scheduled, a suitable planning time, completion of project construction and commencement of project operations on scheduled time is vital.

Government requires construction and commencement of service delivery at scheduled time to avoid any public hostility. Moreover, in some cases of delay, the government may need to provide substitute to meet the demand in short term. For instance, if there is delay in commencement of service of hostel then government need substitute for students' residence. Similarly, in MEET if medical apparatus is not installed at scheduled time the government must arrange the substitute. Furthermore, in case of a long delay, government may cancel the agreement that is also a failure for PPP project.

For SPV, the time is also crucial. The inflow of cash for SPV in terms of unitary charge (i.e. rent from government or collection from users of facility) begins after the commencement of service delivery while the debt instalments are due at specified time irrespective of commencement of service delivery. For instance, In MEET and hostel project government started the payment of rent after the installation of apparatus and commencement of hostel service respectively. Therefore, for SPV commencement of operation at scheduled time is critical.

Although meeting scheduled time is crucial, whereas, a few factors may cause the delay in any phase (i.e. planning phase, construction phase or commencement of operations) of PPP project. For instance, delay in approvals from government, lengthy documentation and excessive changes in design may increase the planning time. Similarly, the delay in material availability, technological imports and lengthy inspections may delay the construction and commencement of service delivery. Thus, PPP project time consists of three crucial timelines; suitable planning time, in-time construction and commencement of service delivery.

This dimension of time is consistent with prior literature (Shenhar et al., 2001, Ika, 2009; Ika \& Thuillier, 2010) but for small projects "commencement of operation at scheduled time" is the only item used to measure it. Due to importance of all phase of PPP projects, this study suggests inquiring about planning and construction time as well.

b) Cost- The second most important aspect of PPP project success is cost effectiveness. Cost of the PPP project includes construction cost and operation cost/maintenance cost. Moreover, construction and operational costs are associated. The quality of material used in construction or installation stage affect the frequency of maintenance at operation stage.

For government cost is vital and cost should be minimal because eventually government or public pays the cost of project. Based on budgeted construction and maintenance cost both contracting parties settles the unitary charge. In few cases unitary charge can be revised to settle any increase in maintenance cost, whereas, government do not contribute in any increase of construction cost.

For SPV, any increase in cost is crucial as it affects the cash flows and profit margin. SPV divides the cost into finance, construction 
and operational cost. According to agreement, all three costs are incurred by the SPV. Similarly, SPV also incurs any sudden increase in cost. Though, in some cases of increase in maintenance cost, government may increase the payment of unitary charge based on agreement. Moreover, maintenance cost affects the budgeted cash flows as SPV must start the repayment of the debt at scheduled time. Though, government pays rental charges if equipment or building is in working according to KPIs. Thus, the frequent maintenance may affect cash inflows for SPV.

The dimension of cost effectiveness is aligned with prior literature $(10,12,20,21,23)$. Nonetheless, prior literature measures cost by using one item "project operated within the budget" $(26,27)$. Due to importance of construction and maintenance cost this study suggests measuring the cost by using construction cost and budgeted cash flows (maintenance cost).

c) Quality of Service- For PPP project success the other criterion is quality of service. The PPP project must deliver the quality of the service in accordance to the KPIs that are stated in agreement. For instance, the type and specifications of biomedical equipment is stated in agreement and the SPV must install the apparatus according to the KPIs. For the government quality of the service is important because the government seeks private sector involvement for the better quality of the service. Similarly, for SPV service quality is vital because government may stop the unitary charges or may impose penalties if the service standards are not according to KPIs. In addition, these penalties affect the profit margins. Furthermore, Malaysian government applies PPP arrangements in critical public sectors like; health, education, security and infrastructure, therefore, quality is crucial issue. The low quality of services may lead to public hostility.

This dimension is consistent with prior literature $(11,19)$ but this study suggests to measure the quality of service with respect to specific KPIs mentioned in agreement rather than comparing with general threshold.

This study highlights the quality Phenomenon (Appendix B). In case, the quality of service is low, the unsatisfied beneficiaries create hostility i.e. students may create hostility if service of hostel project is low. For low service quality, government may stop the rental payment or impose penalties that affect the SPV cash inflows. Low cash inflows tend SPV to delay debt instalment which affect the debt provider. In worse situation project operations may shut down. Thus, quality phenomenon affects all stakeholders.

d) Objectives in Profile- For every PPP project, ministry officials develop a need statement that stats objectives of project in a profile. Generally, all these objectives are announced publicly and available on website of ministry. One of the main objectives is Value for Money (VFM) i.e. achieving maximum service with low cost at standard quality. Furthermore, technical experts of UKAS defines the VFM ratios for each project and set the threshold values for each ration. The PPP project must achieve the VFM ratios. For all ministries of government of Malaysia, profile objectives and VFM are one of the main concerns as auditor general of Malaysia inspects VFM and achievements of profile objectives on yearly basis. Munns and Bjeirmi (28) and Ika (11) postulated that achievement of specific objectives, is one of the dimensions of the success. For PPP projects achievement of VFM is the one of the specific objectives. Therefore, this study suggests the inclusion of VFM item in construct of success.

e) Stakeholder Satisfaction- Interviewees revealed four main stakeholders; government, SPV, debt financer and public/user that is consistent with prior literature $(13,29)$. A PPP project should satisfy all these major stakeholders that have different objectives Government desires to fulfil all its objectives in provision of public service, SPV needs to achieve the budgeted profit margin, debt-provider requires the in-time repayment and public needs satisfactory service with low cost. Shenhar et al. (12), Ika (11) and Ika and Thuillier (10) consider a project successful if it satisfies the stakeholders.

However, the findings of interviews also revealed lack of usefulness of one-dimension, future preparation or expansion of market or fulfilment future need. One PPP project is developed for specified objectives and demands. Based on specific demand, experts prepare budgets. In PPP projects, management do not account any budget for future marketing or expansion. For increase in demand, the government launches a separate project. Sometimes government expands the current project. This type of expansion is considered a new project because a separate planning and agreement is prepared for such expansion. For instance, in case of need of more rooms in current hostel, the government/university may expand the hostel or build a new hostel, but it is considered as a separate project. Nevertheless, government need statement account the future demands and create plans for PPP projects that are connected to each other. For example, the ministry of health possesses the plans of new clinics for future demand. Therefore, unlike normal business project, future preparation or market expansion is not carried out for a specific PPP project.

Based on the prior discussion, this study develops the definition of PPP project success, "A PPP project success means delivery of the desired service quality to the beneficiaries at scheduled time in budgeted cost that satisfies the major stakeholders i.e. equity provider, SPV (Special Purpose Vehicle)/Private Partner, government and beneficiaries".

\section{Conclusion}

The involvement of both public and private parties and their difference in perception about critical issues differentiate PPP projects from other projects. Therefore, it is essential to investigate the applicability of current success definition to the PPP projects. To achieve the objective, this study has applied phenomenological research method by conducting interviews. The results of interviews have revealed that PPP project success is different than other projects. Although dimensions of success are same except one. In addition, three phases planning, construction (installation) and operation affect the project success in terms of time, cost and quality.

The discussion based on findings of interviews concludes that PPP project success depends on completion on time within budgeted cost, delivery of good quality of service based on KPIs, achievement of objectives in profile and stakeholder satisfaction. In addition, completion on time means completing all phases (planning, construction and operation) at scheduled deadlines, meeting budgeted cost refers to maintaining construction within budget and achieving budgeted cashflows and quality of service refers to delivery of service according to KPIs. Furthermore, achievement of objectives connotates to accomplishing specific objectives and achieving VFM ratios. Additionally, satisfaction of stakeholder includes satisfaction of government, SPV, debt provider and users of service. However, due to specific demand and specified concession period "preparation for future" is not included in success dimension. These findings of study contribute in field of PPP and may help the researchers in quantitative research to test impact of other variables like risks, success factors, risk management process and find their significance to PPP project success. The quality phenomenon explains that satisfaction of all stakeholders depends upon the good quality of service.

\section{References}

[1] Ismail S. Critical success factors of public private partnership (PPP) implementation in Malaysia. Asia-Pacific J Bus Adm [Internet]. 2013;5(1):6-19. Available from: http://www.emeraldinsight.com/doi/10.1108/17574321311304503

[2] Ismail S. Factors attracting the use of public private partnership in Malaysia. J Constr Dev Ctries. 2013;18(1):95-108.

[3] Official Portal of Public Private Partnership Unit (UKAS) Background [Internet]. [cited 2018 Jul 27]. Available from: http://www.ukas.gov.my/en/latar-belakang

[4] Ahmad U, Ibrahim Y, of MM-IR, 2017 undefined. Public private partnership in Malaysia: The differences in perceptions on the 
criticality of risk factors and allocation of risks between the private and public sectors. Int Rev Manag Mark [Internet]. 2017 [cited 2018 Jul 27];7(2):138-50. Available from: http://dergipark.gov.tr/irmm/issue/32104/355805

[5] Soomro MA, Zhang X. Failure Links between Public and Private Sector Partners in Transportation Public Private Partnerships. J Traffic Logist Eng [Internet]. 2013;1(2):116-21. Available from: http://www.jtle.net/index.php?m=content\&c=index\&a=show\&catid $=32 \& \mathrm{id}=37$

[6] Beh L-S. Development and Distortion of Malaysian Public-Private Partnerships - Patronage, Privatised Profits and Pitfalls. Aust J Public Adm [Internet]. 2010 Mar [cited 2018 Jul 27];69:S74-84. Available from: http://doi.wiley.com/10.1111/j.14678500.2009.00655.x

[7] Markom R, Rabiah E, Engku A. a Legal Analysis of Successful and ( Bot ) Projects in Malaysia. Int J Bus Soc. 2012;13(2):133-50.

[8] Tan J. The Pitfalls of Water Privatization: Failure and Reform in Malaysia. World Dev [Internet]. 2012;40(12):2552-63. Available from: http://dx.doi.org/10.1016/j.worlddev.2012.05.012

[9] Ke Y, Wang S, Chan AP, Cheung E. Research Trend of PublicPrivate Partnership in Construction Journals. J Constr Eng Manag [Internet]. 2009 Oct [cited 2018 Jul 27];135(10):1076-86. Available http://ascelibrary.org/doi/10.1061/\%28ASCE\%290733 9364\%282009\%29135\%3A10\%281076\%29

[10] Ika LA, Diallo A, Thuillier D. Project management in the international development industry. Int J Manag Proj Bus [Internet] 2010 Jan 26 [cited 2018 Jul 27];3(1):61-93. Available from: http://www.emeraldinsight.com/doi/10.1108/17538371011014035

[11] Ika LA. Project Success as a Topic in Project Management Journals. Proj Manag J [Internet]. 2009 Dec [cited 2018 Jul 27];40(4):6-19. Available http://journals.sagepub.com/doi/10.1002/pmj.20137

[12] Shenhar A, Dvir D, Levy O, planning AM-L range, 2001 undefined. Project success: a multidimensional strategic concept. Elsevier [Internet]. 2001 [cited 2018 Jul 27];34(6):699-725. Available from https://www.sciencedirect.com/science/article/pii/S0024630101000 978

[13] Yescombe E. Public-private partnerships: principles of policy and finance [Internet]. 2011 [cited 2018 Jul 27]. Available from: https://books.google.com/books?hl=en\&lr=\&id=fyHWtz7OepsC\& oi=fnd\&pg=PR11\&dq=Public -

private+partnerships:+principles+of+policy+and+finance\&ots=up4 r7i6RYD\&sig=oe-gggIGHhWqdoxrqhG2Q7eDp3k

[14] Li B. Risk Management of Construction Public Private Partnership Projects. 2003;(May):321.

[15] Ahmad U, Ibrahim Y, and AB-A of A, 2018 undefined MALAYSIAN PUBLIC PRIVATE PARTNERSHIP. abacademies.org [Internet]. 2018 [cited 2018 Jul 27];22:1-6. Available from: https://www.abacademies.org/articles/MalaysianPublic-Private-Partnership-1528-2635-22-SI-155.pdf

[16] Definition \&amp; Models [Internet]. [cited 2018 Jul 31]. Available from:

http://www.pppcouncil.ca/web/Knowledge_Centre/What_are_P3s_/ Definitions_Models/web/P3_Knowledge_Centre/About_P3s/Defini tions_Models.aspx?hkey=79b9874d-4498-46b1-929f37ce $461 \mathrm{ab} 4 \mathrm{bc}$

[17] governance BP-P in urban, 1998 undefined. "With a little help from our friends": public-private partnerships as institutions and instruments [Internet]. Springer. 1998 [cited 2018 Jul 28]. 11-33 p. Available from: https://link.springer.com/chapter/10.1007/978-1349-14408-2 2

[18] Li B, and AA-P partnerships: M risks, 2003 undefined. An overview of public-private partnership [Internet]. books.google.com 2003 [cited 2018 Jul 28]. 3-29 p. Available from: https://books.google.com/books?hl=en\&lr=\&id=Y_hAmDKmJM0 $\mathrm{C} \&$ oi $=$ fnd \&pg $=\mathrm{PA} 3 \& \mathrm{dq}=\mathrm{An}+$ overview + of + publicprivate + partnership \&ots $=\mathrm{Gt}-$ GJDot5F\&sig=GrVAF39BP0VFBUlskO1WQrbnLuw

[19] management JW-I journal of project, 1998 undefined. How can IS/IT projects be measured for success? Elsevier [Internet]. 1998 [cited 2018 Jul 28];16(1):59-63. Available from: https://www.sciencedirect.com/science/article/pii/S0263786397000 227

[20] Pinto J, journal DS-P management, 1988 undefined. Project success. pmi.org [Internet]. 1988 [cited 2018 Jul 28];4(67-72). Available from: https://www.pmi.org/learning/library/project- success-definitions-measurement-techniques-5460

[21] management ADW-I journal of project, 1988 undefined. Measurement of project success. Elsevier [Internet]. 1988 [cited 2018 Jul 28];6(3):164-70. Available from: https://www.sciencedirect.com/science/article/pii/02637863889004 39

[22] Might R, engineering WF-IT on, 1985 undefined. The role of structural factors in determining project management success. ieeexplore.ieee.org [Internet]. 1985 [cited 2018 Jul 28];2:71-7. Available

from: https://ieeexplore.ieee.org/abstract/document/6447584/

[23] Baccarini D. The Logical Framework Method for Defining Project Success. Proj Manag J [Internet]. 1999 Dec [cited 2018 Jul 28];30(4):25-32. Available from: http://journals.sagepub.com/doi/10.1177/875697289903000405

[24] Creswell JW. Research design : qualitative, quantitative, and mixed method approaches. Sage Publications; 2017.

[25] Groenewald T. A Phenomenological Research Design Illustrated. Int J Qual Methods [Internet]. 2004;3(1):42-55. Available from: http://journals.sagepub.com/doi/10.1177/160940690400300104

[26] Ika L, Diallo A, management DT-I journal of project, 2012 undefined. Critical success factors for World Bank projects: An empirical investigation. Elsevier [Internet]. 2012 [cited $2018 \mathrm{Ju}$ 27];30(1):105-16. Available from: https://www.sciencedirect.com/science/article/pii/S0263786311000 469

[27] Cserháti G, Management LS-IJ of P, 2014 undefined. The relationship between success criteria and success factors in organisational event projects. Elsevier [Internet]. 2014 [cited 2018 Jul 28];32(4). Available from: https://www.sciencedirect.com/science/article/pii/S0263786313001 130

[28] Munns A, management BB-I journal of project, 1996 undefined. The role of project management in achieving project success. academia.edu [Internet]. 1996 [cited 2018 Jul 28];14(2):81-7. Available from: http://www.academia.edu/download/44087975/The_role_of_project _management_in_achieving_project_success.pdf

[29] Fischer K, Leidel K, Riemann A, Wilhelm Alfen H. An integrated risk management system (IRMS) for PPP projects. J Financ Manag Prop Constr [Internet]. 2010;15(3):260-82. Available from: http://www.emeraldinsight.com/doi/10.1108/13664381011087515 